\title{
ASUPAN ZAT GIZI PADA IBU HAMIL ANEMIA DAN KADAR FERITIN RENDAH
}

\author{
Muhammad Nur Hasan Syah ${ }^{*}$, Hasnah Supiah', Anang S. Otoluwa ${ }^{3}$, Nurhaedar Jafar ${ }^{4}$, \\ Burhanuddin Bahar ${ }^{5}$ \\ 1. Program Studi S-1 Gizi STIKes Mitra Keluarga, Bekasi-Indonesia \\ 2. Fakultas Kesehatan Masyarakat Universitas Hasanuddin, Makassar-Indonesia \\ 3. Fakultas Kesehatan Masyarakat Universitas Hasanuddin, Makassar-Indonesia \\ 4. Fakultas Kesehatan Masyarakat Universitas Hasanuddin, Makassar-Indonesia \\ 5. Fakultas Kesehatan Masyarakat Universitas Hasanuddin, Makassar-Indonesia
}

*Korespondensi: Muhammad Nur Hasan Syah | STIKes Mitra Keluarga|anca.gizi@gmail.com

\begin{abstract}
Abstrak
Pendahuluan: Pola konsumsi wanita di Indonesia pada umumnya mengandung zat besi kualitas rendah. Sumber bahan makan lebih banyak dari bahan sayuran dimana kadar zat besi pada sumber nabati diketahui memiliki kualitas besi yang rendah dan untuk penyerapan memerlukan bantuan zat pendorong. Tujuan dari penelitian ini adalah untuk menganalisis perbedaan asupan zat gizi pada ibu hamil berdasarkan kadar hemoglobin dan kadar feritin.

Metode: Penelitian ini adalah penelitian kuantitatif dengan rancangan cross-sectional. Sampel pada penelitian ini berjumlah $71 \mathrm{ibu}$ hamil. Pengumpulan data selama 2 bulan, September - Oktober 2012. Pemeriksaan Hemoglobin dilakukan dengan cara cyanmethemoglobin dan kadar besi dengan menggunakan metode HPLC.

Hasil: Hasil yang diperoleh adalah 32,4\% anemia dan 5,6\% memiliki kadar feritin rendah. Berdasarkan analis pada kedua kondisi memiliki asupan energi rendah, yaitu 42\% Angka Kecukupan Gizi (AKG). Asupan protein cukup sekitar 70\% AKG dan 68\% AKG. Aupan zat gizi mikro dibagi menjadi dua bagian, vitamin E, vitamin C, tiamin, riboflavin, niasin, dan seng memiliki asupan yang rendah yaitu 20-50\% AKG. Bagian lainnya, folat dan besi memiliki asupan sangat rendah yaitu $<20 \%$ AKG.

Kesimpulan: Asupan zat gizi pada ibu hamil anemia dan kadar feritin rendah memperlihatkan asupan yang rendah dibanding AKG. Disarankan ibu hamil dapat diberikan edukasi untuk meningkatkan pengetahuan tentang konsumsi makanan bergizi seimbang.
\end{abstract}

Kata Kunci : Anemia, Feritin, Ibu hamil

\section{Diterima 27 Oktober 2018; Accepted 30 Desember 2018}

\section{PENDAHULUAN}

Masalah gizi di Indonesia dan negara berkembang pada umumnya masih didominasi oleh masalah gizi kurang. Bahkan masalah gizi pada kelompok umur tertentu mempengaruhi status gizi pada periode siklus kehidupan berikutnya. Masalah gizi pada setiap fase kehidupan akan saling terkait, misalnya jika ibu hamil KEK dan Anemia maka akan berisiko melahirkan anak Berat Badan Lahir Rendah (BBLR), pendek (stunting), anemia pada bayi yang dilahirkannya, dan dapat berimplikasi kepada kesehatan ibu dan anak. Berdasarkan data World Health Organization (WHO) pada tahun 2005, bahwa setiap tahunnya wanita yang bersalin meninggal dunia mencapai lebih dari 500.000 orang. Menurut Survey Demografi Kesehatan Indonesia (SDKI) pada tahun 2005 Angka Kematian Ibu (AKI) di Indonesia yaitu 262/100.000 Kelahiran Hidup, sedangkan Angka Kematian Bayi (AKB) yaitu 32/1000 Kelahiran Hidup. Kematian ibu adalah kematian seorang wanita yang terjadi selama kehamilan sampai dengan 42 hari setelah berakhirnya kehamilan, tanpa melihat lama dan tempat terjadinya kehamilan, yang disebabkan oleh kehamilan atau penanganannya, tetapi bukan karena kecelakaan.

Data riset kesehatan dasar 2007 menunjukkan kejadian anemia ibu hamil di Indonesia sebesar 24,5\% dan kejadian BBLR (11,5\%), sedangkan data Riskesdas 2010 menunjukkan balita gizi buruk dan kurang $(17,9 \%)$ serta stunting $(36,8 \%)$. Masalah gizi ibu hamil banyak mendapat perhatian karena berpengaruh besar terhadap janin dan tumbuh kembang anak.

Menurut pernyataan Bank Dunia (2006) bahwa kekurangan gizi yang terjadi pada masa tersebut akan menimbulkan kerusakan awak kesehatan, pada masa kehamilan anemia memiliki dampak yang signifikan terhadap kesehatan ibu dan janin. Dibeberapa negara berkembang, anemia lebih sering terjadi pada ibu hamil dan prevalensinya dilaporkan bahkan sampai 75\%. Propinsi Sulawesi Selatan berdasarkan SKRT 


\section{Jurnal Mitra Kesehatan (JMK)}

DOI: $10.47522 /$ jmk.v1i1.2

ISSN: 2580-3379 (print); 2716-0874 (online)

pada tahun 1992 prevalensi anemia gizi khususnya pada ibu hamil berkisar 45,5 - 71,2\% dan pada tahun 1994 meningkat menjadi 76,17\%, 14,3 \% di Kabupaten Pinrang dan 28,7\% di Kabupaten Soppeng dan tertinggi adalah di Kabupaten Bone 68,6\% (1996) dan Kabupaten Bulukumba sebesar 67,3\% (1997). Sedangkan laporan data di Kabupaten Maros khususnya di Kecamatan Bantimurung anemia ibu hamil pada tahun 1999 sebesar 31,73\%, pada tahun 2000 meningkat menjadi 76,74\% dan pada tahun 2001 sebesar $68,65 \%$. Faktor yang mempengaruhi terjadinya anemia pada ibu hamil adalah kekurangan zat besi, infeksi, kekurangan asam folat dan kelainan hemoglobin.

Anemia dalam kehamilan dapat berpengaruh buruk terutama saat kehamilan, persalinan dan nifas. Pengaruh anemia saat kehamilan dapat berupa abortus, persalinan kurang bulan, ketuban pecah dini (KPD). Pengaruh anemia saat persalinan dapat berupa partus lama,gangguan his dan kekuatan mengedan serta kala uri memanjang sehingga dapat terjadi retensio plasenta. Pengaruh anemia saat masa nifas salah salah satunya subinvolusi uteri, perdarahan post partum, infeksi nifas dan penyembuhan luka perineum lama.

Anemia yang paling sering dijumpai dalam kehamilan adalah anemia akibat kekurangan zat besi karena kurangnya asupan unsur besi dalam makanan. Gangguan penyerapan, peningkatan kebutuhan zat besi atau karena terlampau banyaknya zat besi yang keluar dari tubuh, misalnya pada perdarahan. Wanita hamil butuh zat besi sekitar $40 \mathrm{mg}$ perhari atau $2 \mathrm{x}$ lipat kebutuhan kondisi tidak hamil. Jarak kehamilan sangat berpengaruh terhadap kejadian anemia saat kehamilan. Kehamilan yang berulang dalam waktu singkat akan menguras cadangan zat besi ibu. Pengaturan jarak kehamilan yang baik minimal dua tahun menjadi penting untuk diperhatikan sehingga badan ibu siap untuk menerima janin kembali tanpa harus menghabiskan cadangan zat besinya.

Status gizi ibu hamil akan sangat berperan dalam kehamilan baik terhadap ibu maupun janin, salah satu unsur gizi yang penting ketika hamil adalah zat besi. Kenaikan volume darah selama kehamilan akan meningkatkan kebutuhan Fe atau Zat Besi. Jumlah Fe pada bayi baru lahir kira-kira $300 \mathrm{mg}$ dan jumlah yang diperlukan ibu untuk mencegah anemia akibat meningkatnya volume darah adalah $500 \mathrm{mg}$ (Carol, 2008).

Penelitian di Kingston Jamaica menyimpulkan bahwa status gizi ibu mempunyai kerkaitan erat terhadap bayi berat lahir bahwa status gizi yang rendah mempunyai korelasi dengan BBLR (Mulyono, 2005). Di RS Surakarta bahwa ibu hamil KEK mempunyai pengaruh signifikan terhadap kejadian BBLR (Pratomo \& Wiknjosastro, 1995).

Selain itu, hasil penelitian di Peru menyatakan bahwa absorpsi besi sangat dipengaruhi oleh zat gizimikro lainnya, suplementasi besi dan zink dapat membantu penyerapan besi sekitar 8-18\% dibanding dengan suplementasi besi saja. Pustaka lain juga mengatakan bahwa asupan Besi dan Seng memiliki hubungan yang kuat. Ini menyatakan bahwa terjadi interaksi antar zat gizimikro (Brown, Wuehler, \& Peerson, 2001).

Penelitian di Bolivia juga menyebutkan dari $95 \%$ ibu hamil anemia di trimester 1, hanya $42 \%$ yang merupakan anemia karena defisiensi besi (Cohen \& Haas, 1999) Serum ferritin merupakan petunjuk kadar cadangan besi dalam tubuh. Pemeriksaan kadar serum ferritin sudah rutin dikerjakan untuk menentukan diagnosis defisiensi besi, karena terbukti bahwa kadar serum ferritin sebagai indicator paling dini menurun pada keadaan bila cadangan besi menurun (Citrakesumasari, 2012)

Kadar feritin dan hemoglobin sering digunakan untuk mengukur anemia defisiensi besi, khususnya pada populasi. Jumlah kandungan ferritin dan hemoglobin dalam tubuh dapat menentukan besarnya cadangan besi tubuh dan besi fungsional yang beredar dalam darah. Dalam metabolisme besi cadangan besi tubuh akan dimobilisasi apabila besi fungsional tidak mencukupi kebutuhan besi tubuh. Bila keadaan ini berlangsung terus menerus dapat menyebabkan terjadinya defisiensi besi hingga kondisi anemia. Selama kehamilan, wanita hamil membutuhkan 1000 besi sedang- kan dari diet harian hanya mampu menyerap $10-15 \%$ besi non heme yang dikonsumsi. Selain itu, pola konsumsi wanita di Indonesia pada umumnya mengandung zat besi kualitas rendah. Sumber bahan makan lebih banyak dari bahan sayuran dimana kadar zat besi pada sumber nabati diketahui memiliki kualitas besi yang rendah dan untuk penyerapan memerlukan bantuan zat pendorong seperti zat asam askorbat.

\section{METODE}

Penelitian ini adalah penelitian kuantitatif dengan rancangan cross-sectional dimana pengambilan data hanya dilakukan satu kali. Pelaksanaan pengumpulan data dilakukan di Kecamatan Bontonompo dan 
Bontonompo Selatan Kab. Gowa, Sulawesi Selatan. Pada bulan September - Oktober 2012. Populasi dari penelitian ini adalah seluruh Ibu hamil yang berada di lokasi penelitian.. Sampel dalam penelitian ini berjumlah 71 ibu hamil, sample dipilih dengan menggunakan teknik purposive sampling.

Alat pengumpulan data yang digunakan adalah kuesioner dalam bentuk pernyataan-pernyataan yang berkaitan dengan data karakteristik ibu hamil, data faktor biomedis (umur, jarak kehamilan, paritas), sosial ekonomi (pendidikan, pengetahuan gizi, pekerjaan), budaya (pantang makanan), keterpaparan asap rokok, pemanfaatan layanan kesehatan (Ante Natal Care). Pengukuran $\mathrm{Hb}$ diukur dengan menggunakan hemocue. Pengukuran kadar Feritin ibu hamil yang diambil dari darah vena mediana cubiti sebanyak 3 cc dan diukur dengan menggunakan metode HPLC Pengukuran antropometrik ibu hamil (berat badan sebelum dan selama hamil, tinggi badan, Lingkar Lengan Atas (LLA) dengan menggunakan timbangan digital dengan tingkat ketelitian $0.1 \mathrm{~kg}$, microtoise dengan tingkat ketelitian $0.1 \mathrm{~cm}$, serta pita meter LLA dengan tingkat ketelitian $0.1 \mathrm{~cm}$. Pengolahan data dilakukan dengan menggunakan program komputer, yaitu Program Nutrisurvey, dan program SPSS for Windows. Data akan dianalisis dengan menggunakan uji statistik, baik yang bersifat deskriptif maupun analitik.

\section{HASIL}

Tabel 1 menunjukkan bahwa umur ibu hamil sebagian besar masuk dalam kategori yang aman melahirkan yaitu $19-29$ tahun sebesar 53,5\% dan umur yang berisiko yaitu 16 - 18 tahun sebesar 4,2\%. Adapun usia gestasi ibu hamil pada umumnya masih dalam trimester 1 sebesar $73,2 \%$, riwayat gravid yang merupakan gambaran jumlah kehamilan yang dialami oleh Ibu hamil menunjukan bahwa sebagian besar memiliki riwayat gravida 1 sebesar 50,7\% dan terdapat 4,2\% yang memiliki riwayat gravida 4 . Riwayat paritas dalam penelitian yaitu banyaknya kelahiran hidup yang dimiliki oleh ibu hamil menunjukkan sebagian besar Ibu hamil belum pernah melahirkan 50,7\% dan terdapat 2,8\% Ibu hamil yang memiliki riwayat paritas 3 . Tingkat pendidikan menunjukkan bahwa ibu hamil sebagian besar termasuk pendidikan tinggi yaitu tingkat SMA $(26,8 \%)$ dan D3/S1 (18,3\%).

Tabel 1. Karakteristik Umum Responden

\begin{tabular}{ccc}
\hline Karakteristik & n (71) & \% \\
\hline Umur (thn) & 3 & \\
$16-18$ & 38 & 4,2 \\
$19-29$ & 30 & 53,5 \\
$30-49$ & 52 & 42,3 \\
Usia Gestasi & 19 & 73,2 \\
Tri 1 & & 26,8 \\
Tri 2 & & \\
Riwayat Gravida & 36 & 50,7 \\
1 & 15 & 21,1 \\
2 & 17 & 23,9 \\
3 & 3 & 4,2 \\
4 & 36 & 50,7 \\
& 22 & 31,0 \\
Riwayat Paritas & 11 & 15,5 \\
1 & 2 & 2,8 \\
2 & & 1,4 \\
3 & 1 & 26,8 \\
Pendidikan & & 26,8 \\
Tidak Tamat SD/Mi & 19 & 26,8 \\
Tamat SD/Mi & 19 & 18,3 \\
Tamat SMP/Mts & 19 & \\
Tamat SMA/MA & & \\
D3/S1 & 13 & \\
& &
\end{tabular}

Tabel 2 menunjukkan bahwa variabel umur berdasarkan status hemoglobin yang anemia lebih tinggi 
rata-rata umurnya yaitu 27,09 tahun dibandingkan dengan ibu hamil yang tidak anemia yaitu 26,25 sedangkan kadar ferritin yang defisiensi juga lebih tinggi rata-rata umurnya yaitu 31,75 tahun dibandingkan dengan ibu hamil yang tidak mengalami defisiensi ferritin. Adapun riwayat gravid berdasarkan status hemoglobin menunjukkan bahwa pada ibu hamil yang anemia dan tidak anemia memiliki riwayat gravid yang hampir sama yaitu 1,83 , namun berdasarkan kadar ferritin, ibu hamil yang mengalami defisiensi ferritin memiliki riwayat gravid yang lebih tinggi yaitu 2,25 dibandingkan ibu hamil yang tidak defisiensi ferritin yaitu 1,79. Adapun riwayat paritas menunjukkan bahwa jumlah melahirkan pada ibu hamil yang anemia dan tidak anemia hampir sama yaitu 0,70 , sedangkan berdasarkan kadar ferritin menunjukkan bahwa ibu hamil yang mengalami defisiensi ferritin memiliki riwayat paritas yang lebih tinggi yaitu 0,75 dibandingkan dengan ibu hamil yang tidak defisiensi ferritin yaitu 0,70.

Pemeriksaan kehamilan oleh ibu hamil ke petugas kesehatan menunjukkan bahwa ibu hamil yang anemia lebih sering mengecek kehamilannya yaitu 1,86x dibandingkan ibu hamil yang tidak anemia yaitu $1,71 \mathrm{x}$, hal yang sama terjadi pada kadar ferritin yaitu ibu hamil yang mengalami defisiensi ferritin lebih sering memeriksakan kehamilannya yaitu $2 \mathrm{x}$ dbandingkan dengan ibu hamil yang tidak mengalami defisiensi ferritin yaitu $1,74 \mathrm{x}$.

Variabel lingkar lengan atas (LILA) menunjukkan bahwa ibu hamil yang anemia memiliki LILA yang lebih besar yaitu $26,45 \mathrm{~cm}$ dibandingkan dengan ibu hamil yang tidak anemia yaitu 25,55, hal yang sama terjadi pada kadar ferritin yaitu ibu hamil yang mengalami defisien ferritin memiliki LILA yang lebih besar yaitu $27,37 \mathrm{~cm}$ dibandingkan dengan ibu hamil yang tidak mengalami defisiensi ferritin yaitu $25,75 \mathrm{~cm}$.

Tabel 3 menunjukkan rata-rata asupan energy lebih tinggi pada ibu hamil yang mengalami anemia dan defisiensi ferritin yaitu masing-masing 896,2 \pm 436,9 dan 881,0 \pm 184,9 dibandingkan dengan ibu hamil yang tidak anemia dan tidak defisiensi ferritin yaitu $849,5 \pm 423,05$ dan $863,7 \pm 435,9$. Hal yang sama terjadi pada asupan protein yang juga lebih tinggi pada ibu hamil yang mengalami anemia dan defisiensi ferritin yaitu masing-masing 49,16 $\pm 4,3$ dan 44,35 $\pm 2,56$, namun rata-rata asupan protein tersebut masih rendah dibandingkan rata-rata $A K G$ protein 67 gr.

Tabel 2. Riwayat ibu hamil berdasarkan status hemoglobin dan kadar ferritin

\begin{tabular}{cccccc}
\hline Jenis & \multicolumn{2}{c}{ Status Hemoglobin } & \multicolumn{2}{c}{ Kadar Ferritin } & Total \\
Variabel & $\begin{array}{c}\text { Anemia } \\
(\mathrm{n}=23)\end{array}$ & $\begin{array}{c}\text { Tidak Anemia } \\
(\mathrm{n}=48)\end{array}$ & $\begin{array}{c}\text { Defisiensi } \\
(\mathrm{n}=4)\end{array}$ & $\begin{array}{c}\text { Tidak Defisiensi } \\
(\mathrm{n}=67)\end{array}$ & $(\mathrm{N}=71)$ \\
& Mean $\pm \mathrm{SD}$ & Mean $\pm \mathrm{SD}$ & $\begin{array}{c}\text { Mean } \pm \mathrm{SD} \\
\text { Mean } \pm \mathrm{SD}\end{array}$ & Mean $\pm \mathrm{SD}$ \\
Umur (thn) & $27,09 \pm 5,54$ & $26,25 \pm 5,32$ & $31,75 \pm 1,71$ & $26,21 \pm 5,35$ & $26,52 \pm 5,37$ \\
Gravida & $1,83 \pm 0,93$ & $1,81 \pm 0,96$ & $2,25 \pm 0,95$ & $1,79 \pm 0,94$ & $1,82 \pm 0,94$ \\
Paritas & $0,70 \pm 0,70$ & $0,71 \pm 0,89$ & $0,75 \pm 0,50$ & $0,70 \pm 0,85$ & $0,70 \pm 0,83$ \\
Frekuensi & $1,86 \pm 1,32$ & $1,71 \pm 1,16$ & $2,0 \pm 2,16$ & $1,74 \pm 1,59$ & $1,76 \pm 1,21$ \\
Cek & & & & & \\
Kehamilan & & & & & \\
LILA $(\mathrm{cm})$ & $26,45 \pm 2,05$ & $25,55 \pm 2,05$ & $27,37 \pm 2,05$ & $25.75 \pm 2,06$ & $25,84 \pm 2,08$ \\
HB & $10,00 \pm 0,92$ & $11,59 \pm 0,54$ & $9,72 \pm 2,08$ & $11,15 \pm 1,01$ & $11,07 \pm 1,01$ \\
\hline
\end{tabular}

Adapun asupan zat gizi mikro yaitu vitamin D lebih baik dibandingkan dengan asupan zat gizi makro (energy dan protein), hal ini ditunjukkan dengan asupan vitamin D yang lebih tinggi dan sesuai dengan AKG vitamin D pada ibu hamil yang tidak mengalami anemia dan tidak defisiensi vitamin D yaitu masingmasing 5,15 $\pm 5,48$ dan 4,76 $\pm 5,17$. Namun rata-rata asupan zat gizi mikro lainnya seperti vitamin $\mathrm{E}$, vitamin $\mathrm{C}$, thiamin, riboflavin, niasin, folat, $\mathrm{Fe}$, dan $\mathrm{Zn}$ ibu hamil lebih rendah dibandingkan dengan AKG vitamin $\mathrm{E}$, vitamin $\mathrm{C}$, thiamin, riboflavin, niasin, folat, $\mathrm{Fe}$, dan $\mathrm{Zn}$ yaitu masing-masing $<15,0 \mathrm{mg}$, $<85$ $\mathrm{mg},<1,3 \mathrm{mg},<1,39 \mathrm{mg},<18,0 \mathrm{mg},<600 \mu \mathrm{g},<26 \mathrm{mg}$ dan $<11,4 \mathrm{mg}$, kecuali vitamin B12 yang lebih tinggi dibandingkan dengan $\mathrm{AKG}$ yaitu $>2,6 \mu \mathrm{g}$.

\section{PEMBAHASAN}

Asupan zat gizi makro (energy dan protein) dan mikro pada ibu hamil masih rendah dibandingkan dengan AKG ibu hamil. Zat besi, asam folat, vitamin B12, protein, piridoksin, vitamin C, tembaga dan vitamin $\mathrm{E}$ diperlukan untuk fungsi yang tepat dalam tubuh. Besi merupakan komponen penting dari hemoglobin dan sebagian besar anemia gizi di dunia ini disebabkan oleh kekurangan zat besi. Kekurangan 
zat besi cenderung paling umum ketika asupan yang tidak cukup untuk memenuhi kebutuhan fisiologis tubuh, misalnya dalam kehamilan, masa bayi dan pada remaja. Infeksi dan infestasi parasit juga penting, karena dapat mengganggu aktivitas sumsum, atau meningkatkan eritropoiesis yang menyebabkan kehilangan darah atau hemolisis. Kekurangan zat besi juga terjadi pada sindrom malabsorpsi. (Mother and Child Nutrition in the Tropics and Subtropics).

Anemia karena kekurangan asam folat dan vitamin B12 kurang umum. Asam folat dan vitamin B12 memainkan peran kunci metabolisme dalam sel dan diperlukan untuk perkembangan normal eritrosit dalam sumsum tulang. Kekurangan asam folat lebih umum daripada vitamin B12, dan sebagian besar terjadi selama kehamilan. Selain kehamilan, kekurangan asam folat dan B12 jarang terjadi kecuali pada malabsorpsi dan penyakit tertentu dari usus.

Hasil penelitian menunjukkan bahwa asupan zat besi pada ibu hamil dari makanan saja tidak cukup (Hwang \& Ji-Yun, 2013). Hal ini terbukti dari laporan sebelumnya bahwa kebutuhan zat besi selama kehamilan tidak dapat dipenuhi oleh zat besi dari makanan saja sehingga diperlulkan suplemen zat besi selama kehamilan guna memenuhi kebutuhan zat besi untuk pertumbuhan janin yang normal/memadai (Milman, 2006). Besi diperlukan untuk pertumbuhan dan perkembangan janin normal serta kebutuhan fisiologis besi selama paruh kedua kehamilan yang tidak dapat dicapai dengan zat besi dari makanan saja. Suplementasi zat besi selama kehamilan secara konsisten meningkatkan kadar feritin dan hemoglobin serta menurunkan prevalensi anemia defisiensi besi.

Tabel 3 Asupan Zat Gizi Berdasarkan Status Hb, Kadar Ferritin dan AKG

\begin{tabular}{|c|c|c|c|c|c|c|}
\hline \multirow{2}{*}{$\begin{array}{l}\text { Jenis Zat } \\
\text { Gizi }\end{array}$} & \multicolumn{2}{|c|}{ Status Hemoglobin } & \multicolumn{2}{|c|}{ Kadar Ferritin } & \multirow[t]{2}{*}{$\overline{\mathrm{AKG}}$} & \multirow{2}{*}{$\begin{array}{c}\text { Total } \\
(\mathrm{N}=71)\end{array}$} \\
\hline & $\begin{array}{c}\text { Anemia } \\
(\mathrm{n}=23)\end{array}$ & $\begin{array}{l}\text { Tidak Anemia } \\
\quad(\mathrm{n}=48)\end{array}$ & $\begin{array}{l}\text { Defisiensi } \\
(\mathrm{n}=4)\end{array}$ & $\begin{array}{l}\text { Tidak defisiensi } \\
\quad(n=67)\end{array}$ & & \\
\hline & Mean \pm SD & Mean \pm SD & Mean \pm SD & Mean \pm SD & Mean \pm SD & Mean \pm SD \\
\hline $\begin{array}{l}\text { Energy } \\
\text { (Kcal) }\end{array}$ & $\begin{array}{c}896,2 \pm \\
436,9\end{array}$ & $849,5 \pm 423,05$ & $881,0 \pm 184,9$ & $863,7 \pm 435,9$ & $\begin{array}{c}2085,6 \pm \\
101,82\end{array}$ & $864,6 \pm 425$ \\
\hline Proten (gr) & $49,16 \pm 4,3$ & $44,35 \pm 2,56$ & $45,87 \pm 1,36$ & $42,48 \pm 2,41$ & $67,0 \pm 0,0$ & $42,67 \pm 2,36$ \\
\hline Vit. D & $3,93 \pm 4,30$ & $5,15 \pm 5,48$ & $4,62 \pm 5,07$ & $4,76 \pm 5,17$ & $5,0 \pm 0,0$ & $4,76 \pm 5,13$ \\
\hline Vit. E (mg) & $4,36 \pm 5,14$ & $2,75 \pm 2,21$ & $3,62 \pm 2,39$ & $3,25 \pm 3,55$ & $15,0 \pm 0,0$ & $3,27 \pm 3,49$ \\
\hline Vit.C (mg) & $38,76 \pm 6,84$ & $22,29 \pm 2,39$ & $24,75 \pm 26,08$ & $27,79 \pm 44,7$ & $85,0 \pm 0,0$ & $27,62 \pm 43,8$ \\
\hline $\begin{array}{l}\text { Thiamin } \\
(\mathrm{mg})\end{array}$ & $0,35 \pm 0,22$ & $0,35 \pm 0,19$ & $0,30 \pm 0,08$ & $0,35 \pm 0,2$ & $1,30 \pm 0,2$ & $0,35 \pm 0,2$ \\
\hline $\begin{array}{l}\text { Riboflavin } \\
\text { (mg) }\end{array}$ & $0,49 \pm 0,49$ & $0,39 \pm 0,29$ & $0,34 \pm 0,12$ & $0,43 \pm 0,37$ & $1,39 \pm 0,02$ & $0,42 \pm 0,36$ \\
\hline Niasin (mg) & $6,49 \pm 2,81$ & $6,65 \pm 3,88$ & $7,75 \pm 1,46$ & $6,53 \pm 3,63$ & $18,0 \pm 0,0$ & $6,6 \pm 3,55$ \\
\hline Folat $(\mu \mathrm{g})$ & $78,13 \pm 4,9$ & $71,82 \pm 36,5$ & $72,25 \pm 8,4$ & $73,9 \pm 4,19$ & $600,0 \pm 0,0$ & $73,86 \pm 40,7$ \\
\hline $\begin{array}{c}\text { Vit. B12 } \\
(\mu \mathrm{g})\end{array}$ & $3,3 \pm 3,03$ & $3,87 \pm 3,8$ & $4,71 \pm 3,77$ & $3,63 \pm 3,57$ & $2,60 \pm 0,0$ & $3,69 \pm 3,56$ \\
\hline $\mathrm{Fe}(\mathrm{mg})$ & $3,93 \pm 4,22$ & $3,69 \pm 3,67$ & $4,18 \pm 1,24$ & $3,74 \pm 3,93$ & $26,0 \pm 0,0$ & $3,76 \pm 3,83$ \\
\hline $\mathrm{Zn}(\mathrm{mg})$ & $3,95 \pm 2,53$ & $4,04 \pm 2,7$ & $4,59 \pm 1,64$ & $3,98 \pm 2,68$ & $11,4 \pm 0,83$ & $4,01 \pm 2,62$ \\
\hline
\end{tabular}

Dengan pertimbangan pengaruh negatif zat besi seperti peningkatan stres oksidatif dan penyerapan kompetitif dengan logam divalen lainnya selama kehamilan, suplementasi besi dengan dosis yang tepat berdasarkan status zat besi ibu hamil harus dipertimbangkan (Hwang \& Ji-Yun, 2013). Penelitian menyarankan bahwa profilaksis besi individu sesuai dengan status serum ferritin, menunjukkan risiko kekurangan zat besi, sebaiknya diutamakan untuk profilaksis umum (Milman, 2006).

Selain itu, bioavailabilitas zat besi dari makanan hewani adalah lebih tinggi dibandingkan zat besi dari makanan nabati karena komposisi tinggi besi hem dan faktor daging. Komponen dalam makanan seperti fitat dan polifenol mengurangi penyerapan dari kedua diet dan besi tambahan. Penyerapan maksimum besi dari suplemen dapat diperoleh ketika tablet dikonsumsi setelah makan (Brise, 1962)

Pola makan yang menyediakan 10-12 mg zat besi per hari, dan setidaknya $40 \%$ dari besi berasal dari daging, akan memberikan jumlah yang cukup untuk orang dewasa normal. Rata-rata diet di Inggris pada tahun 1976 tersedia $12 \mathrm{mg}$ zat besi setiap hari. Dari jumlah ini 15\% diperoleh dari roti putih dan sekitar $23 \%$ berasal dari kue-kue dan produk sereal. Daging disediakan sekitar seperempat dari asupan besi total 
sehingga lebih dari setengah asupan zat besi berasal dari roti, tepung terigu dan daging. Dalam diet ratarata hem besi hanya menyumbang 1-3 mg zat besi per hari dan dalam komunitas petani miskin bahkan kurang.

Pola makan yang salah pada ibu hamil membawa dampak terhadap terjadinya gangguan gizi antara lain anemia. Penelitian juga menunjukkan bahwa semakin kurang baik pola makan, akan semakin tinggi angka kejadian anemia (Herlina \& Djamilus, 2006). Beberapa studi dengan besi radioaktif biologis dimasukkan ke dalam makanan telah membantu pemahaman kita tentang mekanisme serap dan ketersediaan besi dari berbagai makanan. Dengan demikian, besi lebih baik diserap dari sapi dan ikan dibandingkan dengan gandum. Paling sedikit penyerapannya adalah kacang, bayam dan jagung. Secara umum, penyerapan zat besi dari makanan didasarkan terutama pada makanan nabati cukup rendah (1-5 persen) dan penyerapan dari diet yang mengandung jumlah yang cukup dari hewan protein lebih tinggi (810 persen). Penyebab terbesar anemia gizi adalah berkurangnya asupan zat gizi yang berhubungan dengan pola makan yang tidak baik akibat ketidaktahuan dan ketidakmampuan (Suryadi, 2009)

Pada umumnya, besi di dalam daging, ayam, dan ikan mempunyai ketersediaan biologik tinggi. Sementara di dalam serealia dan kacang-kacangan mempunyai ketersediaan biologik sedang. Sementara itu, sebagian besar sayuran, terutama yang mengandung asam oksalat tinggi, seperti bayam, mempunyai ketersediaan biologic rendah. Bentuk besi di dalam makanan berpengaruh terhadap penyerapannya. Besi hem yang merupakan bagian dari hemoglobin dan mioglobin yang terdapat di dalam daging hewan dapat diserap dua kali lipat dari besi-nonhem. Kurang lebih $40 \%$ dari besi di dalam daging, ayam, dan ikan terdapat sebagai besi hem dan selebihnya sebagai nonhem. Besi nonhem juga terdapat di dalam telur, serealia, kacang-kacangan, sayuran hijau, dan beberapa jenis buah-buahan. Konsumsi sumber zat besi hem dan nonhem secara bermakna dapat meningkatkan penyerapan besi nonhem. Daging, ayam, dan ikan mengandung suatu faktor yang membantu penyerapan besi (Almatsier, 2004)

Buah pisang, jeruk, pepaya dan jambu biji merupakan sumber vitamin $\mathrm{C}$ yang dapat meningkatkan optimalisasi penyerapan zat besi nonhem. Masih kurangnya frekuensi konsumsi sumber vitamin ini, bisa menjadi salah satu penyebab masih terdapatnya ibu hamil yang anemia. Kebiasaan konsumsi serealia oleh wanita India, memiliki korelasi hampir linier dengan intake kalori dan zat besi. Wanita dengan kadar hemoglobin di bawah 8,0 g / dl dan berat badan kurang dibandingkan dengan wanita yang tidak anemia memiliki penghasilan yang hampir sama groups. Data ini menunjukkan bahwa anemia menjadi salah satu manifestasi dari keseluruhan ibu yang asupan zat gizinya tidak cukup dan memiliki berat badan kurang (Kalaivani, 2009).

Ada kemungkinan bahwa program pemberian makanan tambahan ditujukan pada peningkatan asupan makanan ibu yang diharapkan dapat memberikan perbaikan status hemoglobin ibu. Hal ini perlu dilakukan karena anemia gizi merupakan kelompok terbesar kedua setelah gangguan gizi kurang energi-protein. Individu yang paling rentan pada periode-periode kehidupan ketika kebutuhan gizi meningkat karena tuntutan pertumbuhan. Di banyak bagian daerah tropis anemia gizi sangat umum karena asupan zat gizi yang tidak memadai dan infeksi parasit atau cacing yang selanjutnya meningkatkan kebutuhan kebutuhan gizi. Di banyak masyarakat yang makmur di Eropa Barat, anemia gizi digunakan untuk menjadi masalah kesehatan masyarakat. Mengingat tingginya prevalensi anemia pada kehamilan dan konsekuensi yang serius pada ibu dan bayi, manajemen anemia pada kehamilan harus menjadi prioritas baik dalam obstetri dan praktek kesehatan masyarakat. Penelitian telah menunjukkan bahwa konsekuensi buruk dari anemia ibu dapat mempengaruhi tidak hanya neonatus dan bayi, tetapi juga meningkatkan risiko penyakit tidak menular ketika anak tumbuh menjadi dewasa dan risiko berat badan lahir rendah pada generasi berikutnya.

\section{KESIMPULAN}

Berdasar dari hasil penelitian maka simpulan yang dapat diperoleh adalah energi dan protein serta beberapa vitamin dan mineral memiliki rata-rata asupan yang lebih tinggi pada ibu hamil yang mengalami anemia dan defisiensi ferritin dibandingkan dengan ibu hamil yang tidak anemia dan tidak defisiensi ferritin. Perlu disarankan peningkatan asupan zat gizi baik secara langsung melalui pemberian suplemen maupun secara tidak langsung melalui penyuluhan dan konseling gizi pada ibu hamil.

\section{REFERENSI}

Almatsier, S. (2004). Prinsip Dasar Ilmu Gizi. Jakarta: Gramedia Pustaka Utama. 
Brise, H. (1962). Influence of Meals on Iron Absorbsion in Oral Iron Therapy. Acta Med Scand, 39-45.

Brown, K., Wuehler, S., \& Peerson, J. (2001). Food and Nutrition Buletin. The Importance of Zinc in Human Nutrition and Estimation of Global Prevalence of Zinc Deficiency.

Carol, J. L. (2008). Handbook of Nutrition and Pregnancy. Amerika Serikat: Humana Press.

Citrakesumasari. (2012). Anemia Gizi: Masalah dan Pencegahannya. Yogyakarta: Kalika.

Cohen, H., \& Haas, D. (1999). Hemoglobin Correction Factors for Estimating the Prevalence of Iron Deficiency at High Altitudes in Bolivia. Pan Am J Public Health, 392-399.

Herlina, N., \& Djamilus, F. (2006). Faktor Risiko Kejadian Anemia pada Ibu Hamil di Wilayah Kerja Pskesmas Bogor. Jakarta: BPPSDMK.

Hwang, \& Ji-Yun. (2013). Maternal Iron Intake at Mid-pregnancy is Associated with Reduce Fetal Growth. Nutrition Journal, 12-38.

Kalaivani, K. (2009). Prevalence and Consequences of Anemia in Pregnancy. Indian J Med Res, 627-633.

Milman, N. (2006). Iron Prohylaxis in Pregnancy-General or Individual and in Wich Dose? Annals Hematologi, 821-828.

Mulyono, T. (2005). Anemia Ibu Hamil dan Hubungan dengan Beberapa Faktor di Kabupaten OKU Provinsi Sumatera Selatan. Jakarta: Fakultas Kesehatan Masyarakat Universitas Indonesia.

Pratomo, H., \& Wiknjosastro, G. (1995). Pengalaman Puskesmas dalam Upaya Keselamatan Ibu: Pilot Project di Beberapa Puskesmas. Jurnal Jaringan Epidemiologi Nasional, 1-8.

Suryadi, M. (2009). Gambaran Anemia Gizi dan Kaitannya dengan Asupan Serta Pola Makan pada Tenaga Kerja Wanita di Tangerang. Jurnal Kedokteran Yarsi, 31-39. 